Utah State University

DigitalCommons@USU

1973

\title{
The ecological role of fire in the Jackson Hole area, northwestern Wyoming
}

\author{
L.L. Loope \\ G.E. Gruell
}

Follow this and additional works at: https://digitalcommons.usu.edu/aspen_bib

Part of the Forest Sciences Commons

\section{Recommended Citation}

Loope, Lloyd L.; Gruell, George E. 1973. The ecological role of fire in natural conifer forests of western and northern America. Symposium held at the annual meetings of the Ecological Society of America and the American Institute of Biological Sicences 3(3): 425-443.

This Contribution to Book is brought to you for free and open access by the Aspen Research at DigitalCommons@USU. It has been accepted for inclusion in Aspen Bibliography by an authorized administrator of DigitalCommons@USU. For more information, please contact digitalcommons@usu.edu.

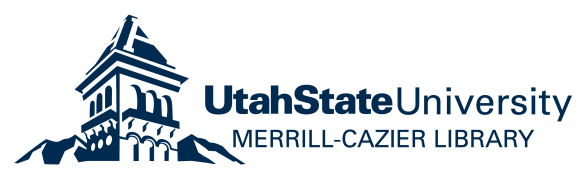




\title{
The Ecological Role of Fire in the Jackson Hole Area, Northwestern Wyoming
}

\author{
Lloyd L. Loope ${ }^{1}$ and George F. Gruelit ${ }^{2}$ \\ Received March $20,19 \% 3$
}

\begin{abstract}
Fire-history investigations in the Jackson Hole area of northwestern Wyoming reveal that most current stands of aspen and lodgepole pine regenerated following extensive fires between 1840 and 1890 and that widespread fires occurred in the 1600s and 1700s. White man's major effect on the fire incidence has been the successful suppression during the past 30-80 yr. Successional changes in the absence of fire include the deterioration of aspen stands, massive invasions of subalpine fir in lodgepole pine stands, great increase in conifer cover, heavy fucl buildups in lodgepole pine and Douglas fir stands, and increase in sagebrush and other shrubs. Steps are being taken, starting in 1972, to allow fire to play a more natural role in Grand Teton and Yellowstone National Parlss. Teton National Forest plans experimental prescribed burning to determine whether fire can stimulate successful aspen regeneration in the presence of large numbers of wintering elk.
\end{abstract}

R. S. Brandegce surveyed forest conditicus on the Teton Forest Reserve for the 1.5. Geological Survey in 1897. His report (Brnndegee, 1899) stated:

3 is only occasionally that tracts of timber of merchantable size are found, and areas containing notable quantities of merchantable forest are few and limited.

This condition appears to be due simply and solely to fires which have swept over the country so compietely and persistently that scarcely any part has been ontirely excmpt from them, while nearly all portions have been burned again and again within a generation ... Under present conditions the tree-bearing regions as a whole decrease, while the aspen areas increase at the expense of those now producing conifers.

The area of Teton Forest Reserve which Brandegee surveyed now comprises most of the Teton National Forest and Grand Teton National Park. Ecological conditions have changed over the past $75 \mathrm{yr}$, mainly

${ }^{2}$ National Park Service, Moose, Wyoming \$3012.

${ }^{2}$ U.S. Forest Service, Jackson, Wyoming $\$ 3001$. due to successful fire suppression. Plant succession in the absence of fire has resulted in an increase in the extent and average age of coniferous forest stands and a deterioration of aspen stands. Shrub cover, especially big sagebrush, has increased markedly. Conifers continue to invade open areas. (See Figs. 1, 2.)

A primary management goal of the $\mathrm{Na}$ tional Park Service for Grand Teton National Park is to maintain the park's ecosystems in as natural a state as possible (Houston, 1971). The U.S. Forest Service has similar objectives for the Teton Wilderness Area of the Teton National Forest. The remainder of the Teton Forest is managed for multiple use, which involves commereial logging and management for wildlife habitat, grazing of domestic livestock, watershed quality, and recreation values. It has becone obvious to both land-management agencies that an understanding of the nature of pristine coosystems and the processes that shaped them is necessary for enlightened managenent. 

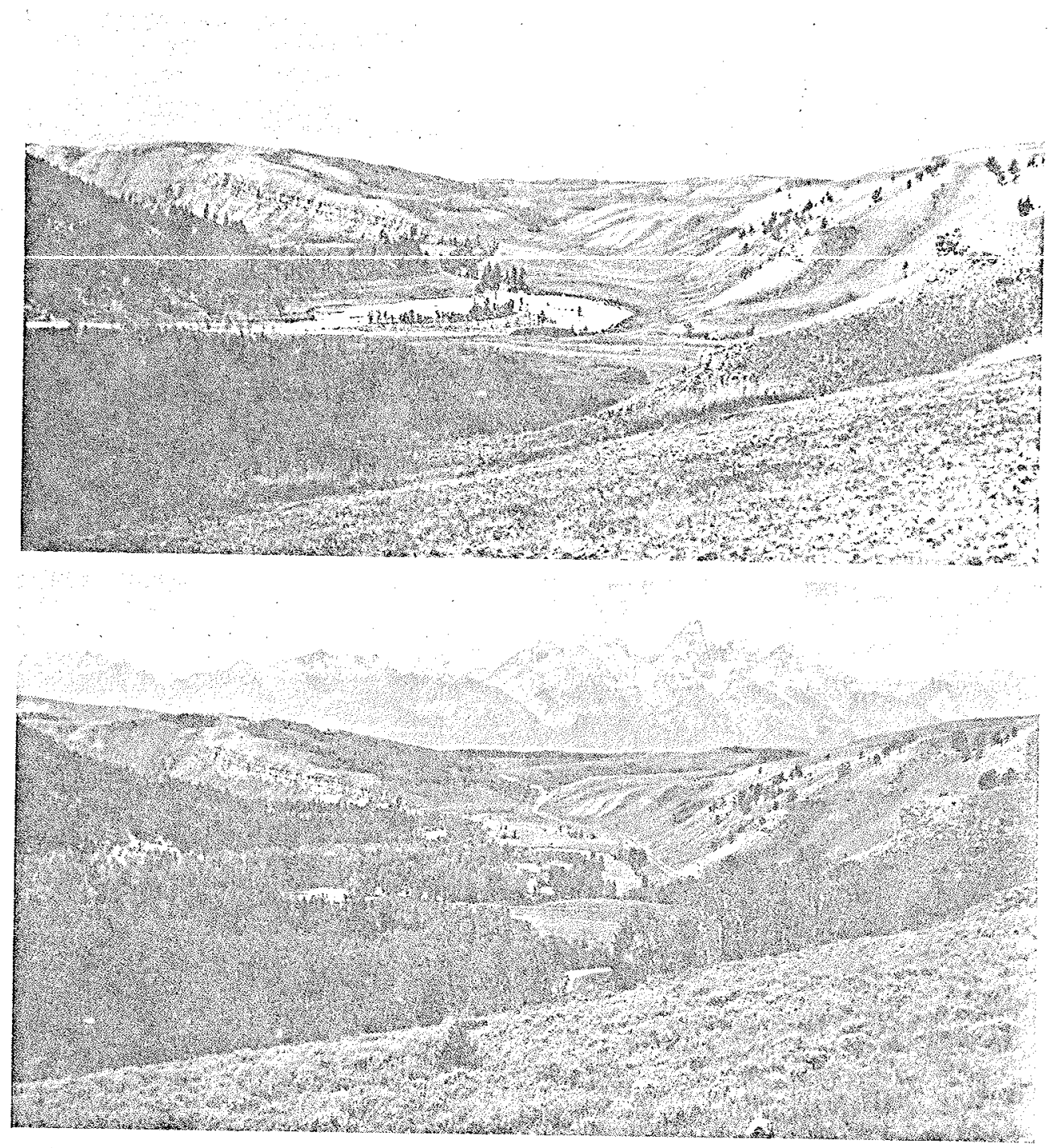

Fra. 1. Lower Gros Ventre Valley, Teton National Forest (Above). 1899. The landscape $20 \mathrm{yr}$ after a major fire. Note the young aspen stands. The vegetation in the foreground is predominantly an herbaceous cover with scattered serviceberry and snowberry shrubs. Courtesy of Wyoming State Archives and Historical Department, Stimson Photo Collection. (Below). July 28, 1971. Aspen stands are mature and approaching decadence, $92 \mathrm{yr}$ after nire. Aspen on distant bench has been largely replaced by Douglas fir. The foreground vegetation is now dominated by big sagebrush.

Our stridies attempt to document the nature of the pristine vegetation patterns of this area and the influence of fire on these patterns. We try to determine the effects of fire and various stages of plant succession on the outstanding wildlife populations of the Jackson Hole area. Field investigations are mainly within Teton National
Forest and Grand Teton National P. with supplemental observations in Yell stone National Park and Bridger Natio i Forest.

\section{THE AREA}

Northwestern Wyoming has five mir mountain ranges-the Teton, Absarolar, 

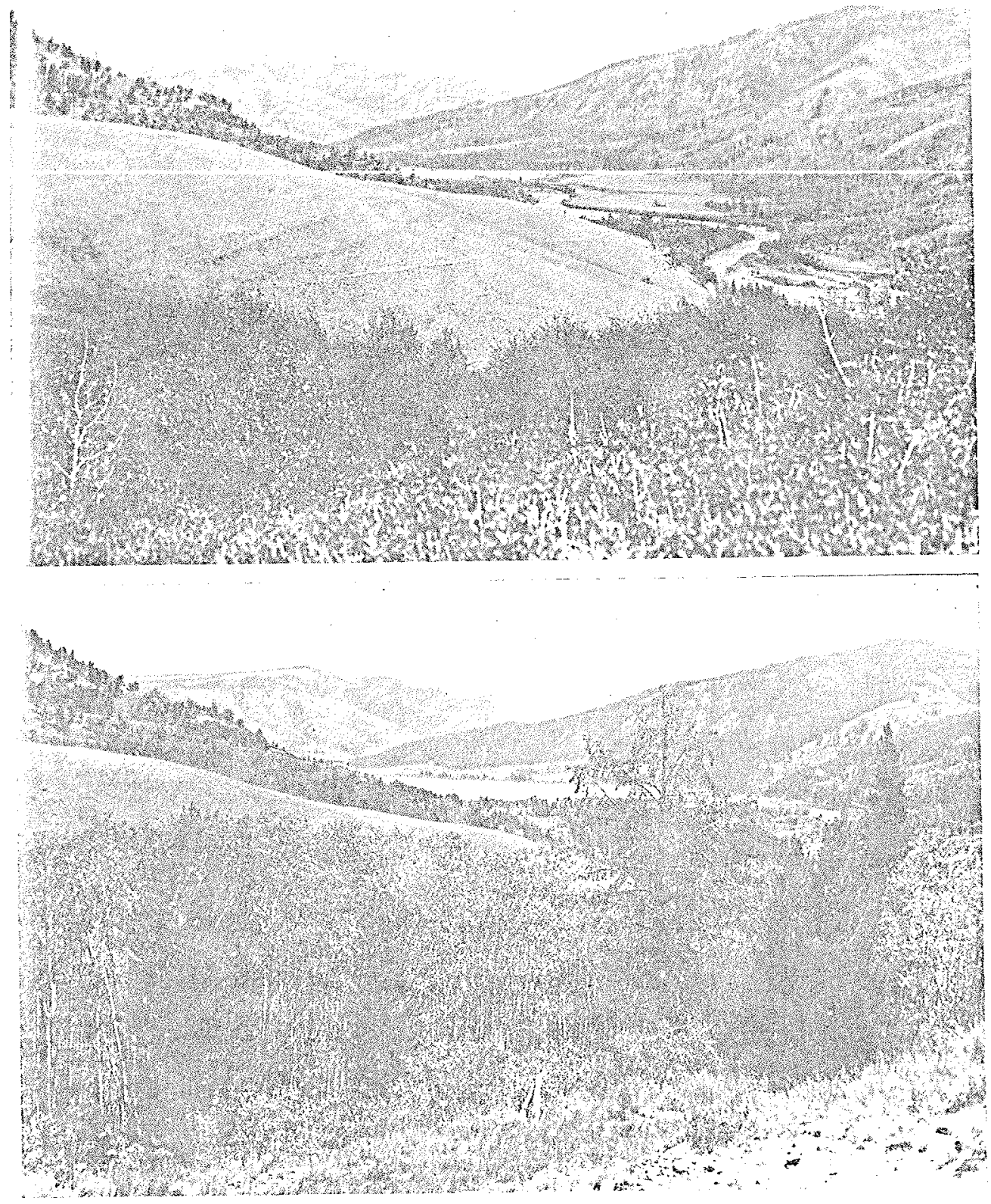

FIg. 2. Lower Gros Ventre Valley (Above). 1899. Taken in the opposite direction from Fig. 1. The foreground of this scene shows a vigorous young aspon stand, which sprouted following the 1879 fire. Young conifors are becoming established under fre-killed snags on the distant slopes at right. Courtesy of Wyoming State Archives and Historical Department, Stimson Photo Collcction. (Below). July 28, 1971. Reproduction is occurring at the margin of the $92-y r-o l d$ aspon stand, but not under the canopy. The distant slopes at right are now forested by a donse stand of Douglas fir. The lake formed following a landslide in $\mathbf{1 9 2 5}$. 
Beartooth, Gros Ventre, and Wind River vicinity of our study area, the Hoback Ranges. Numerous lesser mountain ranges Range, the Mt. Leidy Highlands, the and uplands are present, including, in the Pinyon Pcak Highlands, and the Yollow.

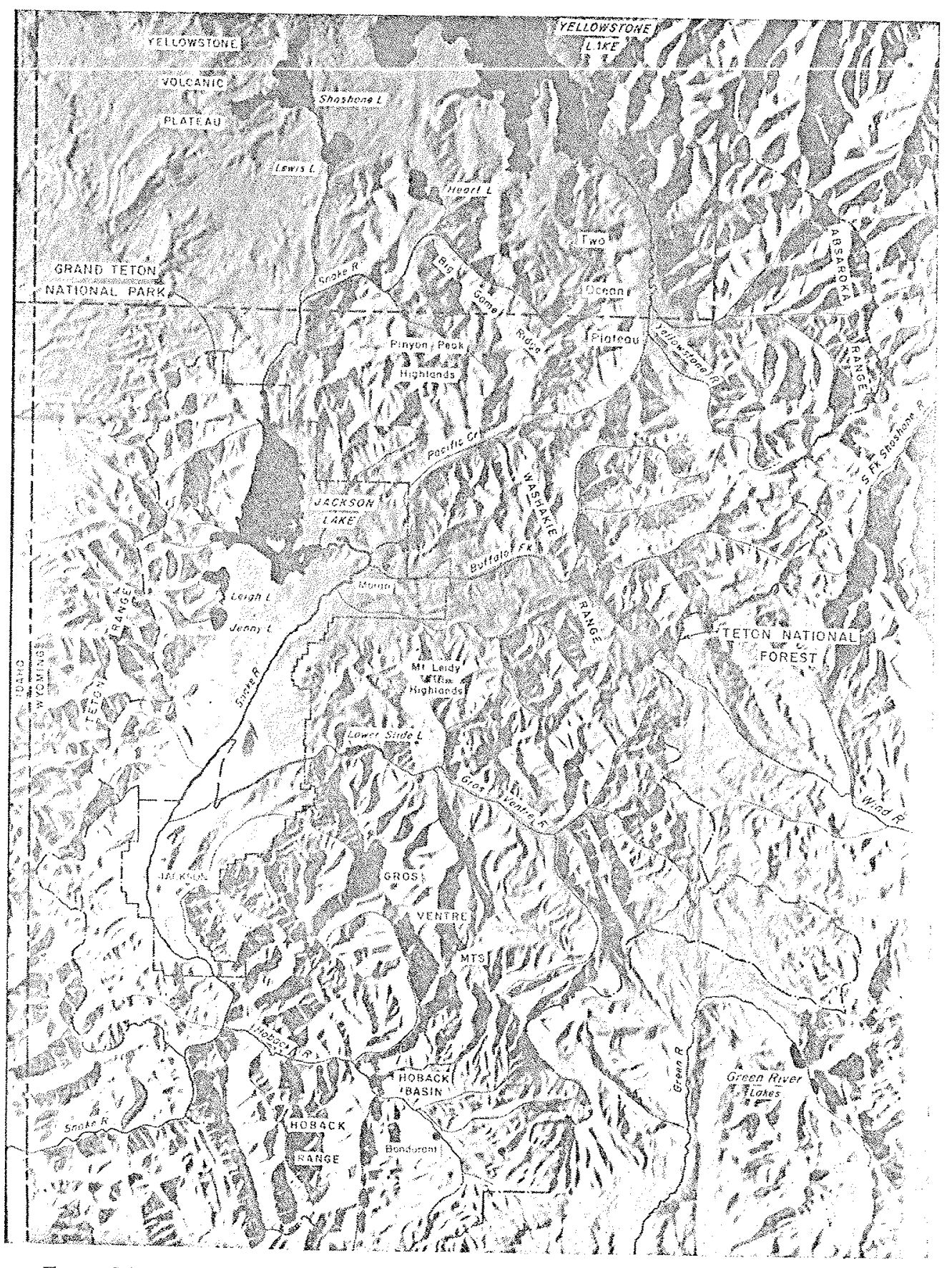

FIG. 3. Map showing location of study area in relation to the major physiographic feature: of northwestern Wyoming. 
ton: Plateau. Figure 3 shows the location of the main study area in relation to the ma or physiographic features of northwe sm Wyoming.

1 a hydrographic divide of the Teton $R s$ comprises the west boundary of

Gr d Teton National Park. The eastern

po. on of the park lies entirely within

Ja son Hole-a flat-floored valley about

65 in long from north to south and 15-25

$\mathrm{kr}$ : wide, drained by the southward-flowing

Sr - River. Our major study area within

T. n National Forest has been east of

so Lern Jackson Hole in the valley of the

$G$ : Ventre River, which rises in the Gros

F. re Mountains.

he area has a complex geologic history,

a a great variety of bedrock types are

e ssed. The Teton Range is composed pri-

n. sily of Precambrian granitic rocks.

$\mathrm{F}$ cozoic limestone and sandstone predom-

$i$ te in the Gros Yentre Mountains. Meso-

z. e shale and sandstone outcrop through-

o : the Gros Ventre Valley. Many of these

Jisozoic formations weather into unstable

chay soils, which are subject to sliding

(Wailey, 1971). The Yellowstone Plateau is

composed of Tertiary basalt and rhyolite.

Picistocene glaciation has had profound effects on the terrain. The valley of Jackson Fole is floored with thick; course outwash deposited by glacial rivers. Numerous moraine deposits occur throughout the area.

\section{VEGETATION}

The vegetation of the Jackson Hole arca consists of a mosaic of nonforested areas and different-aged forest stands, most of which originated following fire. Species composition of parts of the mosaic is determined not only by microclimate and soils, but in large part by the time since the latest fire and by the previous fire history.

The forest portion of the mosaic is composed essentially of eight species of the family Pinaceae and four species of the genus Populus. Lodgepole pine (Pinus con(orta) is often the most ablindant tree spe- cies at intermediate elevations (1850-2400 $m$ ), characteristically occurring in almost pure, nearly even-aged stands of fire origin. Subalpine fir (Abies lasiocarpa), the most abundant tree of subalpine forests, is found from $1850 \mathrm{~m}$ to timberline at about 3050 $\mathrm{m}$. Throughout the upper part of this zone, fir is mixed with Engelmann spruce (Picea engeincarinii). Spuruce somotimes occurs in almost pure stands in moist, fire-protected areas such as are found in canyons at the east base of the Tetons. Whitebark pine (Pinus albicaulis), the other important. component of the subalpine forest, is found from about $2400 \mathrm{~m}$ to $3050 \mathrm{~m}$, and often grows in nearly pure stands just below timberline.

Douglas fir (Pseudotsuga menziesii) is a common species of the lower forest border in this area. Scattered individuals occur up to $2600 \mathrm{~m}$ on south-facing slopes of the Teton Range. Douglas fir forms extensive nearly pure stands on calcareous substrates in the Gros Ventre Mountains and elsewhere in northwestern Wyoming. Limber pine (Pinus flexilis), less common than other conifers, is found at forest-sagebrush ecotones and on very dry south-facing slopes. Aspen (Populus tremuloides is fairly abundant at the lower elevations of the Jackson Hole area, although not nearly so abundant as it is in parts of Utah and Colorado. Aspen often occupies the conifer forest-sagebrush ecotone and stands are frequently mixed with Douglas fir.

Blue spruce (Picea pangens), narrowleaf cottonwood (Populus angustifolia), balsam popular (Populus balsamifera), and black cottonwood (Populus trichocarpa) occur on floodplains in Jackson Hole.

Extensive nonforested areas occur in this region. Sagebrush (including Artemisia tridentata and Artemisia arbuscula), bitterbrush (Purshia tridentata), and rabbitbrush (Chrysothamnus spp.) are important shrubs, which are associated with numcrous species of grasses. Willows (Salix spp.) and sedges (Carex spp.) dominate swampy sites. 


\section{CLIMATE}

Climatic couditions vary widely in Jackson Hole because of the great variation in topography. Mean annual precipitation ranges from over $125 \mathrm{~cm}$ on the Pitchstone Plateau of southwestern Yellowstone Park to less than $35 \mathrm{~cm}$ in the Gros Ventre Valley.

Moran, Nyoming, at an elevation of $2075 \mathrm{~m}$ in northern Jackson Hole has a mean January temperature of $-12^{\circ} \mathrm{C}$ $\left(11^{\circ} \mathrm{F}\right)$, a mean July temperature of $14^{\circ} \mathrm{C}\left(58^{\circ} \mathrm{F}\right)$, and a mean annual precipitation of $53 \mathrm{~cm}$. At least half the precipitation falls as snow from November to April. The average snow depth at Moran on April 1 is $100 \mathrm{~cm}$. Summers in Jackson Hole are short and cool. Snow cover disappears from valley areas in April and May and from high areas as late as July or August. May and June are typically moderately wet months. July is the driest month, averaging $2.5 \mathrm{~cm}$ of precipitation at Moran. Most of the summer rainfall falls in scattered thunderstorms. The prevailing wind direction is from the southwest.

\section{WHITE MAN'S OCCUPATION OF THE AREA}

John Colter, who passed through Jackson Hole during the winter of 1807-1808, is generally regarded as the first white man to cnter the area. Several partics of fur trappers were in the area between 1811 and 1820 , and from 1820 to 1840 there was considerable fur trapping activity in Jaclison Hole. This activity ceased abruptly about 1840 , however, as a result of the sudden decline in popularity of the beaver hat and the orerexploitation of beaver populations. For the 1840-1860 period, there is little or no evidence that white men were present in Jackson Hole (Hayden, 1963; Mattes, 1946, 1948).

Miners, explorers, and hunters were present in Jackson Hole periodically during the 1860s and 1870s. Exploration of the Yellowstone country led to its establish- ment as a National Park in 1872. The firs permanent settler's arrired in 1884 and 188 (Hayden, 1963).

\section{FIRE CLIMATE AND RECENT FIRE HISTORY}

Potential burning conditions vary greatly from summer to summer. The period of highest potential is between July 15 and September 30. August $15-31$ is the most likely period for extreme conditions to occur. Periods of high fire potential are usually brief and are terminated by an abrupt change to cooler weather and/or precipitation.

Data from cross sections of fire-scarred trees and weather records since 1916 sugrest that conditions conducive to extreme fires have occurred at infrequent intervals. The potential for ignition of extensive fires $b y$ lightning storms occurs infrequently, for most lightning storms in the area are accompanied by precipitation. Small it hitning-caused fires were apparently frec in the past. Very large fires were rar. but they did occur periodically when a ccoloj. nation of extremely dry conditions, $c:$ more ignition sources, and high winds incided. Data from fire-scarred trees on: that such conditions occurred in $\mathrm{Ja}$ sol Tole in the years 1856 and 1879 , we fore the initiation of fire-suppl: ion: efforts. Extensive crown fires swept re areas during these years.

Crown fires occur here only und the most extreme conditions. Even wit: ery dry atmospheric and fuel conditions ires generally remain in light fuels on the rest floor unless fanned by strong wind Tl. frequent occurrence of fire-scarred $t$ : it existing forest stands provide evide. "a: creeping ground fres in the past. Of IT: tions made during the 250-hectare cif Creek fire of August 22-29, 1971, in eton. National Forest, confirm this hype as This fire burned in a mixed stand of : uct fir, and lodgepole pine at an eleva! in $2450 \mathrm{~m}$ under extremely dry conditic bu: was not pushed by high winds. Its 
ther was a steady and thorough con-

: $1 \mathrm{~m}$ ion of the moderately heavy ground

iel: with intermittent spolting and igni-

ion if the crowns. Only in areas of excep-

ion : Iy heavy fuels, where the heat of the

tre senerated substantial convection cur-

: in! did a crown fire develop. The crown

ive bed down in lighter ground fuels.

1 or to fre-suppression efforts, it is

ike : that fres during most years were fer

no small. Under burning conditions less

ha extreme, fires would die down and

m lder. Periods of wam weather and in-

re ed wind would revive the blaze. In dry

res 3 , such fires could bum with varying

int sity for several months, affecting large

ier ges.

( ganized fire suppression dates back to

the stablishment of Teton Forest Reserve

in 397. The diary of B. F. Bondurant, a fir guard employed by the U.S. Forest Servic. describes how he extinguished a fire, sc. ved by a lightning strike, which burned on -half acre in Hoback Basin on August 1, 1904 (Sargent, 1963). The U.S. Amy Wi: extinguishing fires in parts of Yellowstune Park in the 1880s, according to Superintendents' Reports (Harris, 1886; Bontelle, 1890). Detection and suppression of fires improved markedly in the $1920 \mathrm{~s}$ and 1930 s with the establishment of fire lockouts throughout most of the forested arca of northwest Wyoming. The remarkable success of suppression efforts is refected in the fact that a total area of about 125 hectares has bumed since 1910 in what is now 130,000-hectare Grand Teton National Park. Highly effective suppression of fires in inaccessible parts of Northwestern Wyoming did not begin until about 1940 .

Moderate detail is available for fire records since 1931. In the 1931-1940 period, thcre were seven fires in Teton National Forest larger than 400 hectares cach. The total area bumed by these fires was over 14,000 hectares. During this same decade, Yellowstone National Park had nine fires over 4.00 hectares, totaling about 18,000 hectares.
Since 1941, Teton National Forest has had no fires as large as 400 hectares. Yellowstone National Park had two such fires, totaling 1400 hectares. These figures reflect increasing effectiveness in fire detection and early suppression in northwestern Wyoming. Fire suppression has been highly sucressful during the past $30 \mathrm{yr}$ despite increased fuel buildups. The rarity of extreme burning conditions during this period has probably contributed significantly to this circumstance.

\section{FIRE HISTORY PRIOR TO 1900}

Evidence from stand age and from sections of fire-scanred trees has been used to investigate the fire history of Grand Teton National Park and parts of Teton National Forest. Numerous very small fires have occurred in the Teton Range because of frequent lightning strikes, but large fires have been rare because of rugged topography and numerous natural firebreaks-especially bare rock. In contrast, no extensive area in the valley of Jackson Hole has cscaped fire for much over $200 \mathrm{Jr}$, and inost areas burned in the interval between 1850 and 1885. Fire-scar and standage data suggest that large fires occurred about 1765 , in the early 1840s, about 1856, and in the interval of 1878-1885. Most forest stands in the valley originated following the fires of 1856 and 1879. Several square kilometers of lo Igopole pine forest burned in the northcrn Teton Range as recently as 1910.

Sampling from the Gros Ventre Valley in Teton National Forest, contiguous with the eastern edge of Jackson Hole, indicates that fres burtacd somewhere in the drainage during cach decade of the 19 th century. However, fres seem to have burned extensive arcas only during the 1840 s, 1870 s, and 1880s. Nost forest stands in the Gros Ventre drainage were affected by one or more fires during the 1840-1890 period. Many stands at higher elevations in the Gros Ventre Nountains burned during this period, too, but other stands escaped. Many open lodgepole pine stands contain numer- 
ous individuals with two or three fire scars from this period. Some of the largest fires occurred about 1842, 1872, and 1879.

Limited sampling of sections of $300-400$ yr-old trees in the Jackson Hole area (mostly Douglas fir) with multiple fire scars suggest that numerous fires occurred in the $1600 \mathrm{~s}$ and $1700 \mathrm{~s}$. Trees of this age may have three or four fire scars, even though a fire generally scars only a small percentage of surviving trees in its path.

The best evidence for comparative fire frequencies in northwestern Wyoming in the 17th, 18th, and 19th centuries comes from Houston (1973). Houston investigated the fire history of the winter range for ungulates of northern Yollowstone Park. Cross sections were obtained from 33 live and 10 dead fire-scarred Douglas firs located at forest-grassland ecotones in the Lamar, Yellowstone, and Gardner River valleys. Vegetation of this area is comparable to Jackson Hole but somewhat drier and warmer. Trees averaged $308 \mathrm{yr}$ old, and eight were over 400 yr old. Individual sampled sections showed an average frequency of scarring of about $50 \mathrm{yr}$, prior to white man's infuence in reducing fire frequency. Comparison of sears from adjacent trees suggests one fire per 20-30 yr. The occurrence of similar: fire dates over wide areas suggests the likelihood of eight or ten large fires in the past 300-400 yr. Fire frequencies were very similar during the 17th, 18th, and 19th centuries. The most recent fire scars were generally no Iater than the 1870s. Only two of the sampled trees on the major study units were scarred in the 1890s, and none of the sampled Douglas firs had been scarred since 1900.

A comparison of Houston's data with our data from Jackson Hole suggests that fire occurred less frequently in Jackson Hole than in the grassland areas of northern Yellowstone Park. Few 400 -y $y^{\circ}$ old Douglas firs in our area exhibit more than four fire scars. For most low-elevation sites in Jackson Hole, we estimate the mean natural fire frequency to have been one fire per $50-100$ yr. Stands at high elevation or protected by topographic peculiarities are typically influenced by fire less often. Tundra habitats may be virtually free of fire's influence.

\section{SOURCES OF IGNITION}

There can be little doubt that forest fires have had a profound influcnce on the ecosystems of northwestern Wyoming for centuries. Organic material produced by photosynthesis in regions with cool climate accumulates at a much more rapid rate than it decays, creating a fuel source (Beaufait, 1971). During very dry conditions of late summer or early fall, which are attained in occasional years, adequate ignition can produce extensive conflagrations. The firc frequency at a given site partially depends on the frequency of ignition. Two major sources of ignition exist-lightning and man.

Nowhere in the world is lightning.such a significant ignition source as in the coniferous forests of westem United State; (A. Taylor, 1971). About $60 \%$ of the mod. ern forest fires in this area are caused $b$ : lightning. Data from northwestern Wyoming support this asscrtion. Lightning if nited $53 \%$ of 857 fires from 1931 to 197 : in Teton National Forest. In. Yellowstor National Park, 56\% of 1228 fires betwee. 1931 and 1967 were ignited by lightnir; (D. Taylor, 1969). That lightning star.; fircs now and has caused them in the past 3 undeniable. We have good data on ti: relative importance of lightning ws man : 3 a source of ignition at present. How did ti 3 past compare with the present in th 3 regard?

It is possible only to speculate on the in portance of aboriginal populations in inf: encing the past fire frequency in the Jar son Hole area. Artifacts from the north $\epsilon]$ of Jackson Lake suggest seasonal occupa $y$ in this valley over 10,000 y.a. (Frisia, 1971). More concrete evidence exists for te periodic occupation of Mummy Cave, a s e $105 \mathrm{~km}$ northeast of Jackson Lake, for the past 9000 yr (Wedel et al., 1968). Abri- 
Im vidence points to the presence of man

a. kson Hole during the past $4500 \mathrm{yr}$.

tho one groups are believed to have

mun $d$ bison and antelope there (Frison,

197.

$\mathrm{T}$ a use of fire by aboriginal man in vari-

arts of the world to drive game in

hum is moderately well documented

St art, 1956). Stewart considers unextin-

sui ed campfires to have been a major ig-

nit: i source for fires in prehistoric times.

No pecifie information is available for the

Ja son Hole area. Early man may have

bec a significant source of ignition there.

Th elimination of aboriginal man from the

sce $:$ in the late 19 th century eliminated

th potential ignition source.

many areas of the west, the explora-

tic and settlement by white man clearly

in. eased the fire incidence. Timbering,

1a. clearing, railroads, and campfires were

co tant sources of ignition, causing some

of the largest fires in recorded history

(Folbrook, 1943). Militant Indians were

blimed for many fres in the Rocky Moun-

tains during the late 19th century (e.g.,

Hanna, 1934; Town, 1899), though some

accounts suggest that their incendiary role

has been overestimated by white historians

(Brown, 1971).

Most evidence suggests that the white man did not greatly increase the fire frequency in Jackson Hole during the 19th century. An occasional wildfire undoubtedly resulted from a poorly placed or unattended campfire during the 1820-1840 furtrapping period. However, data from fire-scarred trees indicate that fires during this period were less frequent than during most decades of the 1800 s. There is little evidence of white man in the Jackson Hole arca between 1840 and 1860 (Mattes, 1948). Only a few records exist of his presence there in the 1860s (Raynolds, 1868; Do Lacy, 1876).

There is abundant documentation for the presence of white man in the region during the 1870 s and enty 1880 s, with the advent of government surveys, ectablishment of
Yellowstone National Park, prospecting and hunting trips, and initial white settlement of Jackson Hole. Travel and habitation in the area were still infrequent, however (Doane, 1877; Baillie-Grohman, 1884; Buxton, 1893; Fryxell, 1932). The remote setting, harsh environment, and limited mineral wealth of Jackson Hole deterred occupancy. Permanent settlement did not begin until 1884. Native accounts completely lack instances of wildfires caused by white man or Indians duming this period.

As previously stated, tree-ring evidence indicates extensive fires during the 1870-1885 period, especially about 1872 and 1879. Historic accounts document fires in 1878,1879 , and 1880 . W. W. Jackson passed through Jackson Hole in the late summer of 1878 and photographed the Tetons from Signal Mountain. He was unsatisfied with the quality of his photographs "because of a smoky haziness (caused by forest fires in the vicinity) that filled the air" (Jackson and Driggs, 1929). Thomas Moran visited the west side of the Tetons in August 1879. Conditions for making sketches were far from ideal throughout the trip because smoke from forest fires became "so dense as almost to obscure the peaks of the Tetons" (Fryxell, 1932). W. A. BaillieGrohman camped at Jenny Lake in August, 1880 but was forced to leare the area when chased by a forest fire several miles to the north of Jenny Lake that was "rumning be. fore a northwesterly breeze" (Baillie-Grohman, 1884). In these accounts, no montion is made of fires being caused by humans.

Observers of forest conditions in northwestern Wyoming in the 1880s and 1890 s felt that white man's carelessness was at least partialiy responsible for the devastation of forests by fire. Hague (1886) recognized that "evidence of forest fires 150 years ago may still be traced," but felt that "disastrous fires took place, caused by the carelessness of white man" following establishment of Yellowstone Park. He felt that "with the coming of the railroad and the crection of hotels, fires stead- 
ily increased," until strict precautions wore enforced by the U.S. Army in the late 1880s. Brandegee's (1899) comments for the Teton Forest Reserve are vague as to the cause of the fires. Taylor (1969) points out that the importance of lightning in igniting fires was not appreciated in the 19th contury, IIe determined that Supcrintendents' Reports for Yellowstone National Park prior to 1899 failed to mention lightning-caused fires. Fircs were thus assumed to be man-caused.

One cannot state with certainty tiat white man did not significantly influence the natural fire frequency in the Jackson Hole area during the period of exploration and settlement. Cortain lines of evidence suggest this, however. These include:

1. Fire-scar evidence from 300 to 400 yr-old trees seems to indicate a fire frequency during the 1600 s and 1700 s roughly similar to that during the $1800 \mathrm{~s}$.

2. There is apparently no correlation betrreen frequency of pcople in the area and frequency of conflagration. (Large arcas bumed in the 1840s and 1850s, when very few or no white men were in the area. Only small numbers were present during the great fires of the 1870 s and early 1880 s. After settlement began in the mid-1880s, few extensive fires occurred.)

3. Narrative accounts are almost entirely lacking for ancidentally or intentionally set fires. Such documentation is abundant for other areas of the rest.

In summary, it appears that the fire regime for the 19th century dedrecd from fre-history investigations in modern forest stands can be interpreted as fairly typical of pristine conditions. Adecluate ignition sources existed before the coming of white man to northwestern Wyoming. Aboriginal man probably startcd fires, intentionally or inadvertently, but suficient lightning fires have been ignited by late-summer storms to assure the existence of fire-influenced forests with periodic erclic disturbances without human ignition. White man's major effect on the fire incidence has been marked reduction of fire frequeney during the past 30-70 yr.

\section{ROLE OF FIRE IN MAJOR ECOSYSTEM TYPES}

\section{Aspen}

The role of firc in aspen ecology is of special concern to land-management agencies of northwestern Wyoming because of the current deteriorated condition of most aspen stands. The failure of aspen reproduction has been a concern in Jackson Hole for over $25 \mathrm{yr}$. Traditionally, this has been blamed on "overbrowsing" by the Jackson Hole elk herd, which was believed to exced numbers that existed in primitive times. More recent evaluations of historic elk numbers suggest a decrease in numbers since primitive times (Cole, 1969; Grucll, 1973). Some changes in elk distributing have occurred, particularly adjacent to winter feedgrounds, but in general tie forage utilization patterns rescmble thr.e of the past. Studies of fire history and $f: e$ ccology suggest that the decline of as $n$ is primarily due to an alteration of e natural fire regime.

In the Rocky Mountains, aspen rep... duces almost entirely by sending up veget . tive shoots (suckers) from the root syst n of a clone, and there is apparently very :tle reproduction by seed. Aspens are rear i $y$ killed by fire. Large numbers of regetat e sprouts are produced following a fire in $n$ aspen stand; 12,000-20,000 stems per 1 :tare is not unisual. Hague (1886) $\mathrm{nr}$. $\mathrm{d}$ that in northern Yellowstone Park as n is "the first tree to spring up upon rece $y$ burned areas" and that "by so doin. it helps to conceal unsightly charred tru s, and adds bright color to the somber il slopes."

Apparently, fire produces a physiolo al stimulation of the root system to senc ap suckers, which is tied to the killing of :ature trees of the clone and is thought $t$. be infuenced by auxins (Farmer, 1962). moval of competing vegetation and he 
Lansing of the stand by disease are other scto s involved (Graham et al., 1963). Not mily re large numbers of suckers produced i) ll ing a fire, but these suckers have ani. growth.

C. apetition among suckers as the stand ley ps causes rapid reduction in the numher stems per hectare. However, suckering intinues for several years after a fire. In a fall of 1971, we made a study of the rel: onship of tree ages in aspen stancls of: Jackson Hole area to the date of the inc recent fire influencing each stand, wh showed that aspen suckering due to ti lation by fire continues for $10 \mathrm{yr}$ or me after the fire. This may be largely due to :e expansion of clones following fire. $\mathrm{Tl}$. age structure of present stands is relat : to levels of browsing by elk and thi sc, which are determined by such fac10. as population densities, forage prefercis ss topography, and availability of 10. ge species other than aspen. We have $10 .:$ d no evidence to suggest drastic incruses in elk browsing from natural condicons, except in the vicinity of sites where eli are unnaturally concentrated when supplied supplementary artificial feed in whiter. There has been a great increase in moose browsing in the past $50 \mathrm{yr}$.

In arens where ungulate browsing is naturally heavy at present (and presumably was heavy in the past), all aspen trees that sprouted following the fires of the 1850-1890 period became established within 10-30 yr after the most recent fire. The greatest intensity of reproduction was generally in the 5-yr period immediately following the fire. Virtually no aspens have become established in these stands within the past 70 yr. For example, in a stand near Tent Creek in the Gros Ventre valley, which originated following a fire 120 y.a., all aspens sampled (19) were over $90 \mathrm{yr}$ old. In a stand near the mouth of Coosewing Creek, which originated following a fire 98 y.a., all aspens sampled (9) were at loast 89 yre old.

In areas where ungulate browsing is light (now and in the past), aspen reproduction and establishment, though most prolific following the fires of 1850-1890, has continued sporadically until the present. However, in most instances, reproduction during the past $70 \mathrm{yx}$ has been insufficient to replace the deteriorating stands.

Individual aspens 200 yr old rarely occur. Stand deterioration usually sets in after an age of about $80 \mathrm{yr}$ is reached. Various diseases, the most important of which are sooty bark canker and heart rot, are the immediate cause of the death of the trees. Invasion of conifers (limber pine, Douglas fir, lodgepole pine, subalpine fir, and Engelmann spruce) occurs in many initially pure aspen stands and sometimes contributes significantly to the deciine of the stands. Mixed stands of aspen and conifer originated following fire on some sites. In most of these stands, the conifers have attained dominance and accelerated the death of aspens through shading and root competition.

Nearly all aspen stands in the Jackson Hole area had their origins following fres between 1850 and 1890. Very little reproduction has occurred since 1900. Most stands are now either in or approaching a eritical period. If no fires occur in the noxt 20-50 yr, many clones will be reduced to a situation in which they no longer contribute significantly to the vegetative cover.

In areas of moderate to light game use, reproduction of aspen on stand margins and under deteriorating stands has been mueh greater during the past $20 \mathrm{yr}$ than during the previous 50 yr (1900-1950). We attribute this incrense in reproductive vigor to the deterioration of parent stands, which accelerated about 20 y.a., when most aspens reached an age of 70-80 yr.

In summary, successful regeneration of aspen stands in the Jaclison Hole area was stimulated by fire in the past. Some suckering occurs now without fire, and, in areas with light game use, such suckers can survive to produce mature trees. Even here, however, reprociuction is generally not suff- 
cient to maintain the stand. In areas with heavy game use, suckers rarely survive.

\section{Lodgepole Pine}

Lodgepole pine is well known as a species that thrives under the influence of fire throughout most of the Rocky Mountains. In many parts of the Rochics, lolgepole has predominantly serotinous cones, which remain closed for many years unless heated above $45^{\circ} \mathrm{C}\left(113^{\circ} \mathrm{F}\right)$ (Towells, 1965). In northwestern Wyoming, however, serotiny is relatively unimportant. Most cones open without heat, and the seeds are scattered without fire. However, lodgepole pine has abundant seed production and is a successful invader after fire if there is an adequate seed source nearby. The reproductive potential of nonserotinous lodgepole is suggested by the establishment of large numbers of seedlings on mineral soil exposed in rondcuts. The widespread occurrence of living fire-scarred lodgepoles suggested that individual trees often survived past fires and served as a seed source for the new stand. The probability also exists that, when a fire killed an cntire stand, enough seeds from unopened mature cones survived the fire to contribute substantially to the sced source for a new stand.

After lodgepole pine stands attain an age of 80-100 yr (and the trees a diamcter of $20-25 \mathrm{~cm}$ ), they become susceptible to atm tack by mountain pine beetles (Dendroctonus ponderosae), which lay eggs in the phlocm so that trees are girdled by the feeding larvae. As age and diameter increase further, lodgepoles become increas. ingly susceptible to attack (Roe and Amman, 1970). Most stands in the arca have thus been recently vulnerable to beetle attack, which has killed $10-45 \%$ of the trees over 5 in. $(13 \mathrm{~cm})$ d.b.h. (diameter at breast height) in much of Grand Teton National Park and Teton National Forest in the past $12 \mathrm{yr}$ (Klein et al., 1972). The mountain pine beetle, a native insect, is a highly significant ecological factor that has infuenced lodgepole pine ecosystems for millennia. The high percontage of lodgepole stands in a susceptible stage at present, due to fire suppression, has presumably resulted in high bectle populations over an unprecedented expanse of forest. Photographs taken before 1900 show that some mature stands of lodgepole were decimated by mountain pine bectle belore the advent of successful fire suppression, however.

Within 10-20 yr after a fire in a lodgepole stand, a dense level of stocking is usually attained. Typical $90-y r-o l d ~ s t a n d s$ sampled in Jackson Hole have 1700-2300 trees per hectare larger than $10 \mathrm{~cm}$ d.b.h. Many dead stems of suppressed indiriduals are usually present. The forest floor is highly shaded in such a stand, and there is generally no lodgepole reproduction. Reproductive success of subalpine fir in the understory is variable. At an age of about $120 \mathrm{yr}$, typical lodgepole stands have 800-1050 stems per hectare. Most stands of this age have been affected considerably by mountain pine beetle attack. With ircreased sunlight from thimning of the stand and reduced competition, fir reproduction increases.

At an age of about $200 \mathrm{yr}$, only abor it 400-650 mature lodgepole pines per hecta: romain. The stands have suffered high mo: tality from mountain pine beetle and $b c$ come increasingly susceptible to windthror. Large openings in the canopy occur, ar 1 lodgepole reproduction commences. I I many 200-yr-old stands, the number if lodgepole scedlings and saplings is great? than those of fir. In the absence of fire, sut 1 stands might take several hundred mo? years for fir to attain dominance. The su stantial fuel accumulation in old lodgepo ? pine stands predisposes such stands to fir : which perpetuate lodgepole dominance.

\section{Subalpine Fir}

Subalpine fir might be termed the " $\mathrm{c}$ " max" conifer species for much of the Jac" son Hole country. It has increased greaty in importance due to fire suppression a $d$ is the primary species invading lodgcpole 
vinc tands and many aspen stands. Its in-

wa ing importance and its value as moose

fro :e may have been a contributing fac-

tor o the increase in moose population

lev in Jackson Hole since 1900.

$I$, like spruce, is easily killed by fire.

If : abundant seed source exists near a

hu: for can become established in a mixed

sta I with lodgepole. A pure, dense lodge-

pol stand sometimes has little fir reproduc-

tio at an age of 120 yr. Generally, by an

:gr of $80-100 \mathrm{yr}$, substantial fir reproduc-

tic has begun in a lodgepole stand. With-

ou fre, shade-tolerant fix would virtually

res sce lodgepole in most stands within

$25 .-400 \mathrm{yr}$ after a fire. Fir invasion, how-

er , contributes to the fuel buildup. In

co bination with the fuel from dead lodge-

$p c$ a pines, a fre that will reinitiate the

cle becomes likely.

\section{E gelmann Spruce}

Reed (1969) and Oosting and Reed (1952) found spruce-dominated forests at elevations from $2700 \mathrm{~m}$ to timberline in the Wind River and Medicine Bow Mountains, ropectively. In the Gros Ventre Range, nearly pure spruce stands are largely confined to the higher elevations (2400-3050 m). In the Teton Range, spruce-dominated forests are found primarily in sheltered canyon bottoms and slopes from $2080 \mathrm{~m}$ to $2400 \mathrm{~m}$. The spruce stands of the Tetons are characteristically on the west sides of lakes at the base of steep slopes. Fires are therefore much less frequent than in less sheltered areas. Large individuals of spruce, up to $1.2 \mathrm{~m}$ in diameter, occur in these forests, which are located mainly at the east base of the Teton Range.

Spruce trees are casily killed by fire, and regeneration is usually slow following fire. The age structure of these stands suggests that even these old-growth spruce forests depend on fire for their establishment, because the stands consist of nearly erenaged spruce, with very little spruce reproduction. The situation resembles that described by Bloomberg (1950) for spruce on the east slope of the Canadian Rockies in Alberta.

Where an adequate seed source and suffcient moisture are present, spruce regenerates following fire and may form mixed stands with lodgepole pine. Douglas fir often establishes individuals in such a postfire stand. Since few lodgepoles survive beyond the age of $200 \mathrm{yr}$, an almost pure stand of spruce occupies the site from 200 to 500 yr following a fire. During this stage, subalpine fir often comprises less than $10 \%$ of the basal area of the stand. But spruce regeneration is minimal after the lodgepole canopy closes. As the age of the stand increases, spruce reproduction approaches zero, except on rotting logs and in openings with exposed bare mineral soil. The accumulation of an organic layer at the soil surface and the low light penetration apparently inhibit spruce seedling establishment. Seedlings of subalpine fir are 10-20 times as abundant as those of spruce in these stands. Oosting and Reed (1952) found a similar ratio of fir seedlings to spruce, but felt that high mortality of young fir resulted in maintenance of a climax spruce community. The nearly even-aged structure of the dominant specics here strongly suggests that this community is not "climax."

It appears that fir would eventually replace spruce here in the prolonged absence of fire. The tremendous fuel buildups that accumulate as the spruce canopy breaks up predispose the stands to fre. No present stands cxhibit a late stage in the hypothetical succession from spruce to fir.

Spruce is conspicuously uncommon in Indgepole forests of valley areas of Grand Teton National Park. This appears to be partly duc to past fire history, which has obliterated a seed source, and partly due to modcrately dry late-summer conditions. Fir seeds are larger than spruce seeds and contain much moxe food for utilization by seedlings (Fowells, 1965; Oosting and Reed, 1952). Seedling fir can develop a root system more rapidly than spruce-an im- 
portant adaptation where soil moisture is marginal. A few mature spruces oceur in these valley lodgepole pine forests, and occasional seedling establishment occurs.

In the Gros Ventre Valley, spruce commonly invades lodgepole pine and aspen stands on north-facing slopes. In this area, a seed sourco for: spruce survived past fires in moist pockets. Moisture from seepage often contributes to spruce establishment.

\section{Whitebark Pine}

Above $2600 \mathrm{~m}$, whitebark pine often colonizes areas in spite of its large sceds, which require transport by squirrels, chipmumks, and birds for dispersal. Near Amphitheatre Lake in the Teton Range a nearly pure stand of whitebark pine has become established following a fire about 200 y.a. North of Mt. Berry, in the northern part of the Teton Range, mixed stands of whitebark pine and lodgepole pine occur on an area that bumed about 225 y.a. The forcst on the summit of Mt. Berry burned about $90 \mathrm{y} . \mathrm{a}$. The reproduction of this burned area is about $75 \%$ whitebark pine and $25 \%$ lodgepole pine.

\section{Douglas Fir}

Extensive stands of Douglas fir occupy the lower slopes of the Gros Ventre Mountains on sedimentary rocks and north-facing slopes at low elevations in eastern Jackson Hole. In much of northern Jackson Hole, Douglas fir is found in special edaphic situations-shallow soils, ridges, and south-facing slopes. On higher-elevation sites, Douglas fir may be seral to subalpine frr, but it maintains itself for sereral centuries and is perpetuated by periodic disturbance.

Fire in the past played a major role in Douglas fir forests by maintaining an open condition through periodic ground fires. Crown fires undoubtedly occurred in areas of heavy fuel accumulation. The thick bark of Douglas fir allows mature trees to survive most ground fires.

Pure stands of Douglas fir with a mixed age structure on north-facing slopes of Blacktail Butte, a prominence in southeastern Grand Teton National Park, illustrate particularly well the past role of fire and the need for the return of fire to natural ccosystems. Lightning fires swept across the sagcbrush flats in the past and ignited these forests every 25 to $100 \mathrm{yr}$. Large, thickbarked Douglas firs, up to $1.6 \mathrm{~m}$ in diameter, have as many as four or five fire scars, some of which date back to the 1600s. The most recent fire, which burned in 1879 , affected most of the Butte and left only the larger trees.

From field observations and from reports in the litcrature for similar ecosystem types (Lyon, 1971), the course of plant succession since the 1879 fire can be postulated. In the summer following the burn, a lush growtl of herbaceous species such as fireweed bccame established, due to an abundant source of nutrients and full surlight. Scouler's willow and quaking aspen, sprout. ing from undamaged root systems, attaine? heights of $1-2 \mathrm{~m}$ during the first year an: continued rapid growth during the next 2 . yx. The invasion of Douglas fir seedling. was slow.

After about $50 \mathrm{yr}$, such a dense growt of Douglas fir saplings was established th: competition became intense. The trees gre in such proximity that branches on the low hali of the trmks died. Aspens and willon died or persisted as relict individuals. Tl dark forest floor was covered with shad: tolerant pinegrass.

In 1972, 93 yr after the 1879 fire, the: is a considerable fuel buildup on Blackt. Butte from dead Douglas fir branches ar rrood skeletons of aspen and Scouler: willow. If a fire were to reach these stanc. most of the young Douglas firs would is killed, but many of the large, thick-barke: trees would probably survive.

If fire suppression is continued, it is po . sible that fire could be prevented from co: suming the Blaclatail Butte Douglas on stands for another 50-100 yr, but not in:definitely. In the interim, fuel accumul:- 
iio would continue to build up to the noi where a fire would very likely kill all

Do as firs-even those with the thickest

bar. The ecological consequences of such

: would likely prove highly unfavor-

ab: since aspen and willow would have de-

ter ated beyond the point of potentially

su sîn vegelalive reproduction. Alsô,

the eed source for Douglas fir would be

$\mathrm{dr}$ ically diminished.

Sa brush and Other Shrubs

re periodically swept the sagebrush

fle of Jackson Hole and the Gros Ventre

$V$ : ey. Big sagebrush and low sagebrush

I: emisia tridentata and Artemisia arbus-

ch ) are readily killed by fire. Grasses and

ot a herbaceous plants fourish following

$t$ i nutrient relcase and reduction of com-

po tion for soil moisture. Sagebrush pro-

di es abundant seeds and is capable of

reid reinvasion on sites where competition

f] an grasses is less serere. The grass cover

es ablished on productive soils can exclude

missive sagebrush seciling establishment

fo: many years. Bagebrush seedlings gen-

eally become established on disturbed sites such as pocket gopher mounds or areas trampled by wildlife or domestic livestock.

Near Blacktail Butte, on productive soils where sagebrush is very dense at prescnt, mologist Frank Bradley of the 1872 Haydee survey party reported that "large areas of sage had been burned off, and the grasses had g.own up densely, forming fine pasturage and on these we again encountered antelope. ." (Bradley, 1873). Comparisons of scenes in old photographs with present conditions indicate little change in sagebrush cover on very coarse solls but a considerable increase in cover of sagebrush and other shrubs on finer-textured soils with greater water-holding capacity. We attribute the increase in shrub cover primarily to naiural plant succession in the absence of fire. In many localities of the west, and probably in portions of Jackson Hole, heavy range use by cattle or sheep has been a contributing factor in shrub in- vasion of grasslands. Reduction of fine fucls due to livestock foraging has had a definite influence in reducing fire frequency throughout much of the west (Leopold, 1924; Humphrey, 1958).

Fire greatly infuences the shrub composition of various community types. Whereas big sagchrush and low sagebrush are killed even by low-intensity fires, many shrub species are stimulated by fires. Willows (Salix spp.), silver sagebrush $\left(A 3^{2}-\right.$ temisia cana), bitterbrush (Purshia tridentata), rabbitbrush (Chrysothamnus nauseosus), serviceberry (Amelanchier alnifolia), chokecherry (Pmuns virginiana var. melanocarpa), snowberry (Symphoricarpos spp.), mountain ash (Sorbus scopulina), and snowbrush ceanothus (Ceanothus velutinus) are some of the shrubs of northwestern Wyoming that may resprout after aerial parts are killed by fire. With many of these species, the stage of growth, the intensity of the fire, and the available soil moisture are critical factors determining whether the plant is killed or stimulated.

\section{ROLE OF FIRE IN MATNTATNING MEADOWV AND SAGEBRUSH- DOMINATED HABITATS}

Lodgepole pine is invading sagebrush flats on alluvium along the margins of forested moraines in Grand Teton National Park. In the Gros Ventro Valley, a similar. invasion is occurring at forest margins. In the Jackson Hole area, recurrent fire scems to have been an important factor in deterring substantial invasion of lodgepole pine into some sagebrush sites. Soilmmoisture conditions in sagebrush flats preclude establishment of lodgepole seedlings except in rare farorable years with abundant moisture. Oswald (1966) found that the years 1912, 1925, and 1927 were exceptionally favorable for estabilshment of lodgepole seedlings in the alluvial sagebrush areas along the forest margins in Grand Teton National Park. When a fire kills trees in this situation, it may take years fos them 
to reinvade. In contrast, sagebrush reinvasion can be very rapid.

When a lodgepole pine seed source is deficient, as it may be for high elevation burns, subalpine fir, Engelmamn spruce, and whitebark pine become established in burned areas. Many such burns are above the elevational limits of lodgepole or are on unfavorable substrates for its establishment. Reforestation of high-altitude areas takes place very slowly. The importance of fre in maintaining open areas at high elevations in western United States is well documented (Stahelin, 1943; Fonda and Bliss, 1969; Billings, 1969). However, other factors are often involved in the maintenance of subalpine meadows. Despain (1971) has emphasized the importance of edaphic factors in maintaining meadows in the Bighorn Mountains. Most subalpine meadows in the Jackson Hole area appear to be maintained by edaphic conditions, for little conifer invasion is occurring. Massive meadow invasions are occurring in parts of Yellowstone Nationai Park, however.

\section{INELUENCE OF FIRE ON WILDLIFE HABITAT}

The vegetation mosaic produced by a natural fire regime results in a diverse array of wildlife habitats. When fre is exeluded from the landscape, plant succession leads to a greater expression of "climatic climax" vegetation than would otherwise be present. Research in other parts of the west has suggested that early successional stages favor most wildife species.

The infrequency of fire in the Jackson Hole area during the past 75 yr makes a local interpretation of fire's influence on wildlife habitat difficult. There is a critical need for recently burned areas for study purposes. Until we have new burns to study, interpretations can only be made from inference. Only a few tentative generalizations are warranted by the available evidence. However, logic siggests that wildlife populations which evolved under the influence of periodic fire would be best adapted to habitats in early stages of plant succession.

One of the more obvious changes in wildlife habitat due to fire exclusion is the loss of much willow and aspen habitat once used by beaver. Old, barely discernible dams and gnawed stems attest to a more widespread occurrence of these animals in the past. Now that most regetation is in a late stage of succession, the once abundant food source has greatly declined, and so has the beaver.

On the other extreme, the evidence, strongly suggests that mule deer have benefited from fire suppression. From foodhabitat studies in the west, it is well established that big sagebrush is very often the staple food item in the winter diet of mule deer. Big sagebrush is highly vulnerable to fire and was generally of a low density and scattered occurrence on winter ranges in former years. With exclusion of fire, tha density of sagebrush greatly increase? Some other preferred shrub species also i: creased in availability. The widespread i. crease in the critical carrying capacity $f$ winter range appears to be the princil 1 reason for mule deer population increas 3 over pristine levels.

Traditionally, moose have been as: ciated with seral habitats. Interestin : enough, the moose population in northwe. ern Wyoming was very low during the 1 i century, when frequent fires maintair: $d$ much eariy successional vegetation. I e moose population in Jackson Hole has :tually increased with advancing success: 2. Several contributing factors are undou :edly involved, but a primary influence: >pears to be an unprecedented increase in subalpine fir-the staple food item in ue dict of a large segment of the moose po: lation. In coniferous forests of Jack on Holc, the present carrying capacity or moose is apparently higher than wen much of the forest was in early stage: of succession.

Advanced succession has been favor ble to cavity-nesting birds such as the tree 
wlow, mountain bluebird, house wren, ho ntain and blackcapped chickadees, yelov: bellied sapsucker, woodpeckers, and ec shafted flicker. These species utilize old Sis $2 n$, which are very often rotten in the wes er and susceptible to the boring of the Ia ucker, woodpecker, or flicker. Opporin ties for carity nesting in young aspen tot ds are minimal.

\section{WANAGEMENT INPLICATIONS}

T on National Forest

ire is a natural phenomenon and has br $\mathrm{n}$ the agent responsible for periodic ren: val of the vegetative cover. Strict control 0 fre during the past three-çuartcrs of a ce tury has largely eliminated its natural $r r$ in ecosystems of the Jackson Hole a ea. Some of the environmental effects and n anagement implications of this longs. unding policy are just now surfacing. We a.e now beginning to undcrstand that c) anging the effect of one natural force (ire) in the ecosystem has caused the system to respond in certain unanticipated ways. We have found that the energy hildup in the form of accumulated forest litter and some brush species that are favored by lack of fires (big sagebrush) is crusing the job of fire control to become more difficult and costly. We also find that the change in natural plant succession due to lack of fire has been detrimental to some wildlife species, whereas others appoar to have been favored. It appears that a close reexamination of our fire policies is now in order.

Our investigation suggests that the initiation of a more flexible program-from that of strict fire control to one of fire management-is in order. Appropriate aciions that would help bring fire back into the ecosystem apnear to include:

1. Delineation of the forest into firemanagement zones. In some zones such as valuable timber lands and recreation and developed areas, strict fire control would he practiced. On a large portion of the forest, including wilderness and wildlife habitat, fires would be allowed to burn within predetermined limits.

2. Prescribed burning of certain areas where there is a growing need to return the vegetation to early succession. Candidate types would be livestock and elk ranges where sagebrusb has invaded grassland and aspen is doteriorating. If weather conditions permit, a 125-hectare prescribed burn of this type is scheduled for the Gros Ventre winter range in 1973. High priority for prescribed burning should also be made for extensive conifer types where there is a need to break up the fuel and thereby reduce the possibility of large-scale fires.

The foregoing approach to fire management with attenclant smoke earries with it the inevitable concern over air pollution. The general public must be made aware that wood smoke composed principally of carbon dioxide and water has been a natural part of the Rocky Mountain ecosystem. In earlier years, a pall of wood smoke hung over the countryside quite frequently during the summor months. Being a natural phenomenon and inevitable, it must be accepted as a natural part of the ccosystem.

\section{Grand Teton National Park}

The National Park Service recognizes the need for allowing fire to play a seminatural role in Grand Teton National Park if the management goal of maintaining or restoring ecosystems to as pristine a state as possible is to be realized. During the winter of 1971-1972 a fire-regetation management plan was formulated for the park and an cnvironmental impact statement was written to cover the effects of its implementation. The plan divides the park into four management zones:

Zone I-All naturally caused fires allowed to burn except under exceptional circumstances (human life endangered, exceptional opportunity for spread to other 
areas, ete). Man-caused fires will be extinguished.

Zone II-Naturally caused fires allowed to burn or not allowed to burn according to judgment of a fire-management committee (depending on firc-hazard conditions). Prescribed fres will probably be necessary here.

Zone III-All fres extinguished unless they can be managed as controlled burns. Proscribed fire will be used here to approximate a natural fire frequency.

Zone TV-Developed areas. Manipulation (logging, planting, ete.) used here to approximate effects of fire or managed for resthetically plcasing appearance.

Additional knowledge of fire bchavior in the area will be necessary before full implementation can be attained. Whonever latesummer weather conditions permit, two prescribed burns are planned-one in a Douglas fir stand and one in an aspen-sagebrush area. The primary purpose of these initial prescribed fres will be for rescarch, for obtaining expertise in preseribel burning, and for public education. Also, starting in the summer of 1972, lightning-caused fires will be allowed to burn in the Teton Range (Zone I). In future years, piescribed buming for actual vegetation management is planned.

\section{REFERENCES}

BAller, R. G. (1971). Landslide hazards related to land use planning in Teton National Forest, nothwestern Fyoming. U.S. Deparlment of Agriculture, Forest Service, Intermountain Re. gion, $131 \mathrm{p}$.

Bumm-Gromman, W. A. (1884). "Camps in the Rockies." Charles Scribner's Sons, New York, $488 \mathrm{p}$.

Benchat, W. R. (1971). Fire and smoke in Montoma lorests. In "Forest Land use and the Invironment." (R. M. Weddle, Ed.), pp. 1-23. University of Montana, Montana Forest and Conserration Experiment Siation, Sehool of Forestry.

Birimas, W. D. (1969). Vegetational pattern near alpine timberline as afrected by fire-snordrift internctions. Vegetatio 19, 192-207.

Btomprerg, W. G. (1950). Fire and spruce. Forestry Chronicle 26, 157-161.
BotTELte, F. A. (1890). "Report of the Supcrintentent of Yellowstone National Park." U.S. Government Printing Office, 23 p.

Brabler, F. J. (1873). "Report of Fronk H. Bradley, Gcologist." U.S. Geological Survey of tho Territories, U.S. Government Printing Office. Banidegen, T. S. (1899). Teton forest reserve House Document No. 5, 55th Congress, $34 d$ session Serisl 8y63. Wastington, D.C.

Browx, D. (1971). "Bury My Feart at Wounded Kúnee." Holt, Rinehart, \& Winston, $487 \mathrm{p}$.

Buxrox, E. N. (1893). "Short Stalks; or Hunting Camps." Edward Stanford, London.

CoLe; G. F. (1969). "The Elk of Grant Teton and Southern Yellowstone National Parks." Unpublished manuscript.

Dis Lacr, W. W. (1876). A trip up the South Snake River in 1863. Historical Society of Montona Contributions I, 113-118.

Despatr, D. G. (1971). The regetation of the Bighom Nountains of Wyoming in relation to substrute and climate. Ph.D. thesis, Universigy of Alberta, $136 \mathrm{p}$.

DosNe, G. C. (1877). "Expedition of Lieutenant G. C. Doane-Fort Ellis, Montana, to Font Mali, Idaho. Oet. 11, 18\%, to Jan. 4, 187" U.S. Department of the Interior, National Pak Service. Photocopy of typed manuscript, $41 \mathrm{p}$.

Fariser, R. E. (1962). Aspen root sucker form ition and apical dominance. Forest science 3 , $403-410$.

Fonda, R. W., Axid Briss, L. C. (1969). For it vegetation of the montane and subalpine zon s. Olympic Mountains, Washington. Ecologi $t$ Monographs 39, 271-301.

Fowelcs, H. A. (1965). Silvics of forest tr. s of the United States. U.S Deparment of At $i$ culture, Forest Service, Agriculiural Handb. No. 271, $762 \mathrm{p}$.

Frison, G. C. (1971). Prehjstoric occupation of the Grand Teton National Park. Naturalist 2 , 35-37.

Frixeer, F. (1932). Thomas Moran's joumes to the Tetons in 1879. Augustana Historical ociety Publication No. 2, 3-12.

Graban, S. A., Harrison, R. P., axd West L, C. E. (1963). "Aspens: Phonnix trees of the Great Lakes region." University of Mich an Press, Ann Arbor.

Grumte, G. E. (1973). An ecological evalue on of Big Game Ridge, Teton Wilderness, $\mathrm{T}$ on National Forest, northwestern Wyoming. "S. Deportment of Agnicullure, Forest Service In press.

Hagee, A. (1886). Unpublished manuscript in the National Archives, Washington, D.C.

HANk, I. A. (1934). The major plant comn nities of the headwater area of the Little Lar nie 
River, Wyoming. University of Wyoming Publiations in Science, Botany I 10, 243-266.

F anIs, M. (1886). "Report of the Superintendent if Yellowstone National Park." U.S. Governnent Printing Office, $13 \mathrm{p}$.

F yden, Ellzabetei W. (1963). "From Trapper o Tourist in Jackson Hole." 48 p.

I LBlook, S. H. (1943). "Burning an Empire." The Marmillan Compony, Now Yople.

I tston, D. B. (1971). Ecosystems of National arks. Science 172, 648-651.

I Justor, D. B. (1973). Wildfires in northern Yelowstone National Park. Ecology. In press.

f MMPrRY, R. R. (1958). "The desert grassland: A history of regeintional change and an analysis of causes." University of Arizona Press, $74 \mathrm{p}$.

cksox, W. H., ani Driges, H. R. (1929). "The pioneer photographer: Rocky Mountain adventures with a camera." The World Book Company, Yonkers-on-Hudson, New York.

"trin, W. H., STrue, I. E., ANo Frandser, L. V. (1972). "How damaging is a mountain pine beetle infestaiion?" U.S. Department of Agriculiure, Forest Service, Division of Timber Management, Ogdcn, Utah.

eopotn, A. (1924). Grass, brush, timber, and fire in southern Arizona. Jounal of Forestry 22(6), 1-10.

EYoiv, J. (1971). Vegetal development following prescribed burning of Douglas îr in southcentral Idaho. U.S. Department of Agriculture, Forest Service Research Paper TNT.105, 30 p.

Mitres, M. J. (1046). Jackson Hole, crossroads of the western fur trade, 1807-1829. The Pacific Northwest Quarterly 37, 87-108.

Mattes, M. J. (1948). Jackson Hole, crossroads of the wostern fur trade, 1830-1840. The Pacific Northwest Quarterly 39, 3-32.

Oosting, H. J., and Reed, J. (1952). Virgin apruce-fir forcst in the Medicine Bow Mountains, Wyoming. Ecological Monographs 22, 69-?1.

Oswasd, E. T. (1966). "A synecological study of the forested moraines of the valley floor of
Grand Teton National Park, Wyoming." Unpublished Ph.D. thesis, Montana State University, $101 \mathrm{p}$.

Rayolds, W. F. (1868). Report on the exploration of the Tellowstone and Missouri Rivers, in 1859-60. 40th Congress, and session, Senate Executive Document Number 77, Serial Number 131\%, Washington, D.C.

RIEN, R. M. (1969). "A study of forest vegetation in the Wind River Mountains, Wyoming." Unpublished Ph.D. thesis, Washington State Universily, $7 \tau \mathrm{p}$.

Roe, A. L., AYro Amman, G. D. (1970). The mountain pine beetle in lodgepole pine forests. U.S. Department of Agriculture, Forest Service Research Paper $I N T-71,31 \mathrm{p}$.

Sargent, Helen C. (1963). Mr. and Mrs. B. F. Bondurant, early pioneers of the Fall River Basin. In "Tales of the Seeds-IKe-Dee," $n$. 229-252. The Sublette County Artists' Guild, Big Miountain Press, Denver.

StAHELIN, R. (1943). Factors influencing the natural restocking of high altitude burns by coniferous trees in the central Rocky Mountains. Ecology 24, 19-30.

STHWint, O. C. (1956). Fire as the first great force employed by man. In "Man's role in changing the face of the earth." (W. L. Thomas, Ed.), pp. 115-133. University of Chicago Press, Chicago.

Tayjok, A. R. (1971). Lightning-agent of change in forest ecosystems. Jounal of Forestry 68, $477-480$.

Throor, D. L. (1969). "Biotic succession of lodgepole pine forests of fre origin in Yellowstone National Park." Ph.D thesis, University of Wyoming, $320 \mathrm{p}$.

Town, F. E. (1899). Bighom Forest Reserve (Wyoming). U.S. Geological Suvoy 19th Annual Report, 1S97-98, 165̃-190.

Wedis, W. R., Hustid, W. M., AND Moss, J. H. (1968). Mummy Cave: Prehistoric record from Rocky Mountains of Wyoming. Science 160, 184-186. 